\title{
Environmental Monitoring of the Sustainability and Productivity of the Agroecosystem of Oilseeds in South-East Kazakhstan
}

\author{
Naziya Suleimenova ${ }^{1 *}$, Gulnar Orynbasarova', Mariya Suleimenova², \\ Alikhan Bozhbanov'², Svetlana Yerekeyeva' \\ 1 Kazakh National Agrarian University, Abay ave., 8, Almaty, 050010, Kazakhstan \\ 2 Almaty Technological University, Tole bi str., 100, Almaty, 050012, Kazakhstan \\ * Corresponding author's e-mail: naziya.suleimenova@bk.ru
}

\begin{abstract}
The purpose of the study described in this paper is aimed at identifying the environmental situation of the agroecosystem and studying the impact of resource-saving technology methods for the cultivation of oilseed rapeseed, ensuring sustainability and productivity of the agroecosystem during environmental monitoring. The object of the study was spring rapeseed of the Maily variety. Experimental studies were carried out using the generally accepted classical techniques, such as experiment and observation, in the form of a multifactorial field experiment. A twofactor field experiment was laid out by the split plots method and based on the methodology for conducting field experiments with oilseeds. The results of the study were obtained using the methods of a soil-protective agriculture system based on the principles of soil protection technology. The studied minimal tillage provides a reduction in the amount of mechanical impact on the soil, restoration and preservation of soil fertility, improvement of moisture supply by leaving the plant stubble and scattering chopped straw after harvesting the previous crop, and replacing deep moldboard tillage with shallow flat-cut tillage. On the basis of the obtained study results, it was proven that the replacement of energy-intensive moldboard tillage with shallow flat-cut tillage (mini-till), ensuring the rational use of soil resources and resource-energy conservation, was feasible. The reconstructed parameters of agrophysical factors of soil fertility were determined, such as density, aggregate composition, and the structure and water resistance of soil aggregates, which ensured the sustainability of the environmental situation of the agroecosystem. It has been established that the soil protection methods of resource-saving rapeseed cultivation technology mitigate the risk and optimize the conditions for the growth and development of crops, where productivity increases to $21.3 \%$, and also provide 29.3 thousand tenges/ha of additional income from each hectare with an increase in the profitability of rapeseed cultivation to $97 \%$ and $108 \%$ under the conditions of South-East Kazakhstan.
\end{abstract}

Keywords: monitoring, environmental situation, agroecosystem, rapeseed, ecosystem sustainability, productivity, oilseeds.

\section{INTRODUCTION}

During the scientific and technological revolution at this stage of development, due to the ongoing technogenic and anthropogenic changes, taking into account their numerous catastrophic impacts [Zarch et al., 2017; Bykova et al., 2014; Shi et al. 2019] in the biosphere, environmental science obtained an applied aspect along with the fundamental one.

Modern fundamental science does not have the ways and technologies to meet the basic needs of a growing population [Tyumentseva, 2018] without destroying the Earth's biosphere. The main sphere from which the anthropogenic impacts emanate is agriculture. Since it is the only sphere of the economy that bears the greatest burden on the environment, it requires the determination of principles for the development of the agricultural sector based on the adaptation measures to the specific conditions of changing the environmental situation of the ecosystem, associated with the rational use of soil, biological and energy resources of the agroecosystem [Kokorin et al., 2008; Ashabokov, 2012]. 
Many scientists [Khalilov et al., 2016; Sycheva and Myuller, 2018; Ashikhmina, 2008; Dmitrenko et al., 2014] proved that some technogenic impacts provoked loss of stability in the ecosystem and the balance of the existing cycles of substances and energy, as a result of which a spontaneous process of self-destruction of the biosphere ecosystem could begin [Murugov and Pinov, 1996; Belkov, 2011]. This circumstance causes increased interest in the study of environmental problems, in the development of scientifically based measures aimed at optimizing the environmental situation of ecosystems [Bykova et al., 2014].

In order to improve the environmental situation of the agroecosystem (optimization of the agrophysical, agrochemical, technological properties of the soil and the phytosanitary state of the soil), the existing traditional technology provides for many methods of soil cultivation, which lead to excessive dispersal and drying of the soil [Ryabtseva, 2019; Dogeev and Khalilov, 2019], as well as destruction and reduction of the soil fertility in the ecosystem. In particular, the share of soil cultivation accounts for $30-40 \%$ of all costs for the cultivation of crops. The traditional technology used is too expensive and cannot withstand competition under market conditions. Therefore, there is a need to develop new, more effective technologies for solving problems, such as a resource-saving soil protection technology using mini-till, with several deviations from the traditional technology [Egorov et al., 2018; Mironova et al., 2019].

At the present stage, energy-saving min-till and zero-till farming are widespread in the Commonwealth of Independent States (CIS) [Minnebaeva, 2011; Khalilov et al. 2016; Magomedov et al., 2017]. The share of farmland plowed using mini-till is $20.1 \%$ in Germany, $29.1 \%$ in Switzerland, $24.5 \%$ in the UK, and $19.6 \%, 17.2 \%$, and $15.0 \%$ respectively in Portugal, Belgium, and Spain. In modern Kazakh and world practice [Karpov et al., 2019; Dogeev and Khalilov, 2019], the most promising soil protection technologies include the resource-saving technologies with minimal or no tillage (no-till).

Modern no-till technologies are aimed at saving, improving, and increasing the efficiency of the use of natural resources through an integrated approach to the existing soil, biological, water resources, and consumables. The conserving technologies with mini-till are involved in preserving and protecting the environment and increasing the sustainability and productivity of the agroecosystem [Suleimenova and Orynbasarova, 2019; Kuandykova et al., 2020].

In this regard, the problem that arose involved organizing special systems for environmental monitoring (observation, assessment, and forecast) of the environmental state of the agroecosystem in places of anthropogenic impact. Therefore, to solve the problem of the agroecosystem in the field of environmental safety under the specific agricultural conditions of the presented study in the South-East Kazakhstan, the soil protection methods (mini-till) of resource-saving technology have been developed. They provide minimal mechanical impact on the soil, leave stubble and scattering chopped straw, preserve soil fertility and optimize the environmental situation of the agroecosystem. The solution to the listed problems of the agroecosystem of the new crop (the rapeseed zone) in the study area is very relevant.

Therefore, the purpose of the study described in this paper is aimed at identifying the environmental situation of the agroecosystem and studying the effect of methods of resource-saving technology (mini-till) for the cultivation of rapeseed, ensuring sustainability and productivity of the agroecosystem during environmental monitoring.

The scientific novelty of this work is that for the first time, to optimize the environmental situation of the ecosystem and increase the productivity of the leading oilseed crop (rapeseed), the effectiveness of soil protection methods (mini-till) as part of resource-saving technologies was studied. The integral abrasion of replacing energy-intensive moldboard tillage, shallow flat-cut tillage with soil protection technology, ensuring the rational use of soil resources and resource and energy conservation, was determined. The reconstructed parameters of the agrophysical factor (soil density, aggregate composition, structure, and water resistance of aggregates) of soil fertility, which provides the optimal environmental conditions for the agroecosystem, were described. It was established that soil protection methods of resource-saving rapeseed cultivation technology mitigate the risk of a decrease in ecosystem productivity, optimize the conditions for the growth and development of crops, where the yield increases to $21.3 \%$, and provide an additional 29.3 thousand tenge/ha of additional income from each hectare with an increase in the profitability rapeseed up to $97 \%$ and $108 \%$ under the conditions of South-East Kazakhstan. 


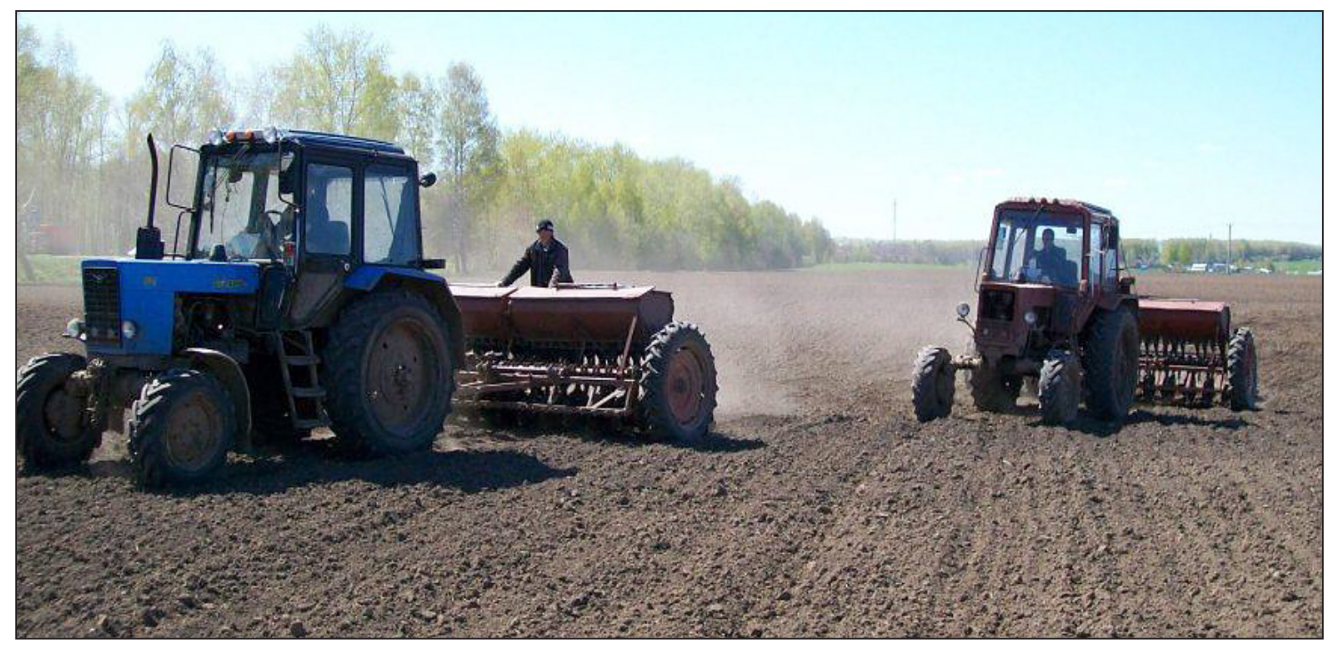

Figure 1. Field experiment layout, rapeseed sowing period

\section{MATERIALS AND METHODS}

The experimental studies were carried out in 2017-2020, on the territory of the Agrouniversity educational and experimental farm of the $\mathrm{Ka}$ zakh National Agrarian Research University (KazNAIU), located in a typical study area of SouthEast Kazakhstan.

The object of the study was spring rapeseed of the Maily variety. The experimental studies were carried out by using the generally accepted classical techniques, namely experiment and observation, in the form of multifactorial field experiments [Kiryushin et al., 2009; Ivanov, 2008; RASKhN. GNU VNII kormov im. V.R. Vilyamsa, 2011]. A two-factor field experiment was laid out, with the method of split plots, according to the method of experimental work [Novikov, A.M. and Novikov, D.A., 2010], as well as the "Methods for conducting field experiments with oilseeds" [Lukomets, 2007].

The results of the study were obtained using the methods of the soil-protective system of agriculture based on the principles of soil protection technology, such as minimizing soil tillage, ensuring a reduction in the amount of mechanical impact on the soil, restoring and maintaining soil fertility, improving the moisture content by leaving plant stubble and scattering chopped straw after harvesting the previous crop as well as replacement of deep moldboard tillage with shallow flat-cut tillage.

The two-factor field experiment for the study "The impact of minimization (mini-till) of resource-saving technology on sustainability and productivity during environmental monitoring of the rapeseed agroecosystem" was laid out based on the following design:

Factor 1, A. Studied in two variants of rapeseed cultivation technology:

$\mathrm{A}_{1}$ : Traditional technology. Soil plowing (with PN-5-35) + $\mathrm{B}_{1}$ : 20-22 cm tillage depth; (the control variant).

$\mathrm{A}_{2}$ : Resource-saving technology, in the framework of which two variants of the second factor were studied.

Factor 2, B. Studied in two variants $-\mathrm{B}_{1}$ : 16-18 cm tillage depth, and $\mathrm{B}_{2}: 12-14 \mathrm{~cm}$ tillage depth. Thus, in the design of the full factorial experiment (FFE), shallow flat-cut tillage is studied in the two following variants:

1. Resource-saving technology + Flat-cut soil tillage at the depth of 16-18 cm (with KPP-2.2) + pulse, $0.7 \mathrm{l} / \mathrm{ha}$;

2. Resource-saving technology + Flat-cut soil tillage at the depth of 16-18 cm (with KPP-2.2) + pulse, $0.7 \mathrm{l} / \mathrm{ha}$;

3. Traditional technology + Plowing soil at the depth of 20-22 cm (with PN-5-35) (the control variant).

The area of the study [Sistema vedeniya selskogo khozyaistva, 2005] is characterized by a continental climate, low air humidity, abundant sunlight, and short but moderately cold winters. The average annual precipitation is $540 \mathrm{~mm}$, where about $300 \mathrm{~mm}$ of precipitation falls during the warm period of the year. The average annual temperature is $7.7^{\circ} \mathrm{C}$.

Field experiments were laid out on meadowchestnut soils with heavy texture. The chemical composition of meadow-chestnut soil [Eleshev et al., 2014] is characterized by a moderate humus 


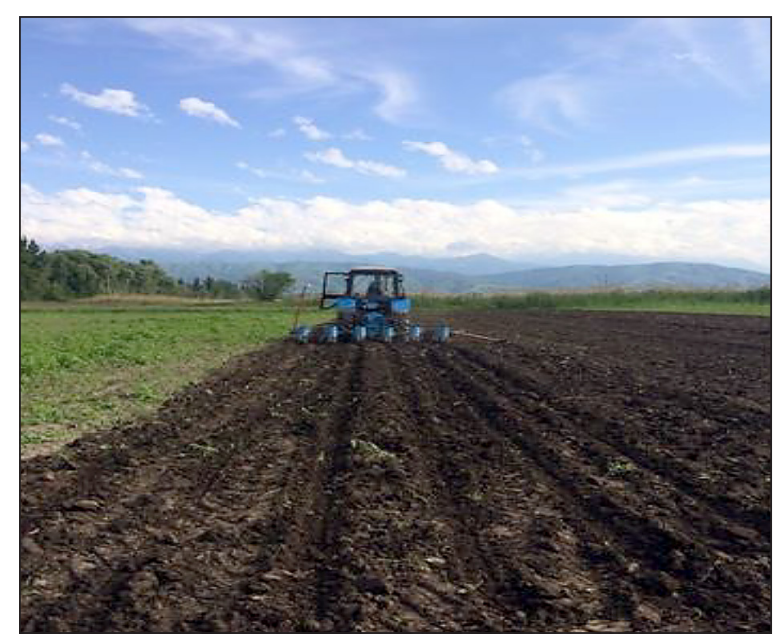

Figure 2. Field experiment layout

content of $4.40-4.45 \%$, easily hydrolyzed nitrogen content of $87 \mathrm{mg} / \mathrm{kg}$, the potassium content of $435.1 \mathrm{mg} / \mathrm{kg}$, and mobile phosphorus content of $22-25 \mathrm{mg} / \mathrm{kg}$ of soil. The meadow-chestnut soil of the studied zone, in terms of its water-physical properties and the level of potential fertility, fully satisfies the conditions for the cultivation of all types of crops, including oilseeds.

The obtained experimental data were processed with the analysis of variance methods [Dospekhov, 1985; Novikov, A.M. and Novikov, D.A., 2010] and when the quantitative variability of the sample volumes of observations was manifested, statistical processing was carried out using a computer program developed by the information and analytical center of KazNAIU.

\section{RESULTS AND DISCUSSION}

While studying the problem of sustainability and productivity of the agroecosystem of oilseeds, environmental monitoring with resourcesaving and traditional technology of cultivation of a valuable oilseed crop, such as rapeseed was carried out. In the study of the environmental situation of the rapeseed ecosystem grown using traditional technology, a negative anthropogenic impact on the environmental state of soil fertility resources was observed. It changes the structure of the arable layer, giving it a loose or lumpy state, as a result of which it undergoes a deterioration in the indicators of agrophysical soil fertility (soil density, soil structure, and aggregate composition decrease), which causes a deviation in the water, air and temperature regimes of the soil.

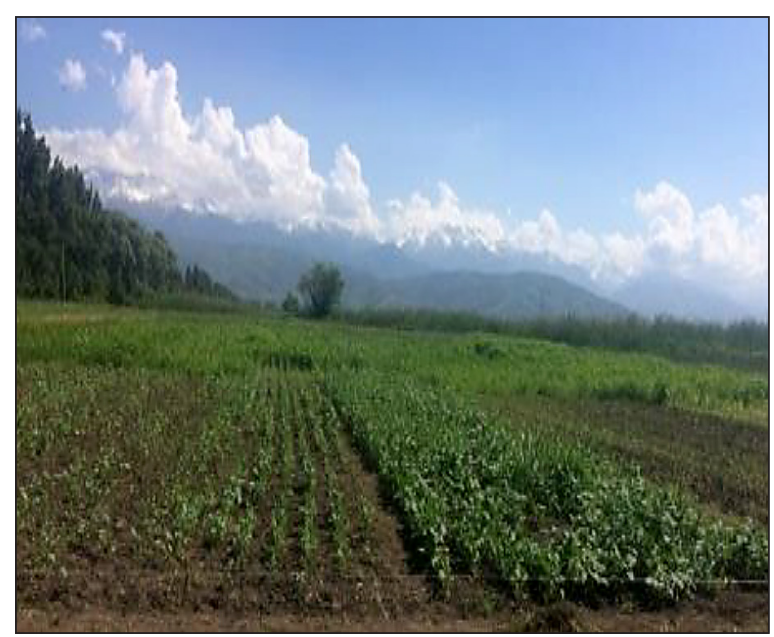

Figure 3. Soybean sowing during the germination and stem extension period

The temperature regime of the rapeseed ecosystem was determined according to the values of the average monthly air temperature $\left(\mathrm{t}^{\circ} \mathrm{C}\right)$ during the growing season of rapeseed, in the 2017-2020 years of the study (Table 1).

It should be noted that the average monthly air temperature for the growing season during the years of the study was between $23.3^{\circ} \mathrm{C}$ and $24.0^{\circ} \mathrm{C}$ with a norm of $18.8^{\circ} \mathrm{C}$, according to long-term data of the average monthly air temperature $t^{\circ} \mathrm{C}$.

On the basis of the results obtained, the performed study revealed that starting from the second decade of April to August, during the growing season of rapeseed, depending on climate change, the average monthly air temperature increased to $4.1^{\circ} \mathrm{C}$ in 2017 and $5.6^{\circ} \mathrm{C}$ in 2020 . The maximum increase in the average monthly air temperature during the growing season indicates an aggravation of the environmental situation of the ecosystem of the studied crop. In the southeast of Kazakhstan, as well as throughout the world, the most problematic event is global warming. The average annual air temperature exceeds the annual norm by $0.8-1.0^{\circ} \mathrm{C}$ [Suleimenova et al., 2018]. In the territory of the study during the cultivation of rapeseed, it exceeds the normal temperature by $1.1^{\circ} \mathrm{C}$ and $4.00^{\circ} \mathrm{C}$ (the norm established at $7.7^{\circ} \mathrm{C}$ ) (Fedotov et al., 2012).

Along with this situation, an increase in the average monthly air temperature, especially during the growing season, is dangerous in the increase in the frequency and repetitiveness of aridity in the territories of studied South-East Kazakhstan. Similar values were obtained when studying the aggravation of the environmental situation, where 
Table 1. Duration of the growing season depending on the temperature regime of the rapeseed ecosystem (in 2017-2020 years of the study)

\begin{tabular}{|c|c|c|c|c|c|}
\hline \multirow{2}{*}{$\begin{array}{l}\text { Years } \\
\text { of the study }\end{array}$} & \multicolumn{3}{|c|}{$\begin{array}{l}\text { Average monthly air temperature } t^{0} \mathrm{C} \\
\text { during the rapeseed growing season }\end{array}$} & \multirow{2}{*}{$\begin{array}{l}\sum \text { of active } t^{0} \text { during } \\
\text { the rapeseed } \\
\text { growing season, } \mathrm{t}^{0} \mathrm{C}\end{array}$} & \multirow{2}{*}{$\begin{array}{c}\text { Duration of vegetation } \\
\text { period for rapeseed, } \\
\text { days }\end{array}$} \\
\hline & $\begin{array}{c}\text { during the years } \\
\text { of the study }\end{array}$ & $\begin{array}{l}\text { according to } \\
\text { long-term data }\end{array}$ & $\begin{array}{l}\text { air temperature } \\
\text { increase by } t^{0} \mathrm{C}\end{array}$ & & \\
\hline 2017 & 23.3 & \multirow{5}{*}{18.8} & 4.1 & $\sum 2,451$ & 120 \\
\hline 2018 & 24.2 & & 5.4 & $\sum 2,310$ & 114 \\
\hline 2019 & 23.7 & & 4.9 & $\sum 2,358$ & 116 \\
\hline 2020 & 24.0 & & 5.6 & $\sum 1,990$ & 110 \\
\hline $\begin{array}{l}\text { The average value } \\
\text { for years of the study }\end{array}$ & 23.8 & & 5.0 & $\sum 2,254$ & 115 \\
\hline
\end{tabular}

another author [Daribaeva, 2019] had concluded that an increased likelihood of low yields as a result of an increase in the frequency and repetitiveness of droughts and aridity in the studied region was especially dangerous.

During the years of the study, the sum of active temperatures, $t^{\circ} \mathrm{C}$ for the growing season of rapeseed, depending on the magnitude of the change in air temperature had increased from $\sum$ $19,900{ }^{\circ} \mathrm{C}$ to $\sum 2,358-\sum 2,451{ }^{\circ} \mathrm{C}$ (Figure 4).

With an increase in temperature of $4.1^{\circ} \mathrm{C}$ in 2017 , there was an increase in the average monthly air temperature from 5.4 to $5.6^{\circ} \mathrm{C}$ in the dry years 2018 and 2020, respectively. A sharp increase in the average monthly air temperature and the sum of active temperatures have a significant effect on the duration of the rapeseed growing season. Depending on climate change during the years of the study, the duration of the growing season had reduced from 120 to 110 days and the average duration of the growing season amounts to 115 days.

Thus, the maximum increase in the average monthly air temperature during the growing season proves the presence of global warming under the conditions of South-East Kazakhstan. The climate change entails instability of the agroecosystem, where the deterioration of soil fertility is observed, which has a significant impact on the moisture supply of crops, growth, development of the crop, and productivity of the agroecosystem.

At the same time, to maximize the use of the evolutionary genetic potential of the crop under study, it must be placed in a kind of environmental niche, where the crop is most productive and can compete in the environment of the agroecosystem [Shalyapina and Guseva, 2007; Filipova et al.,

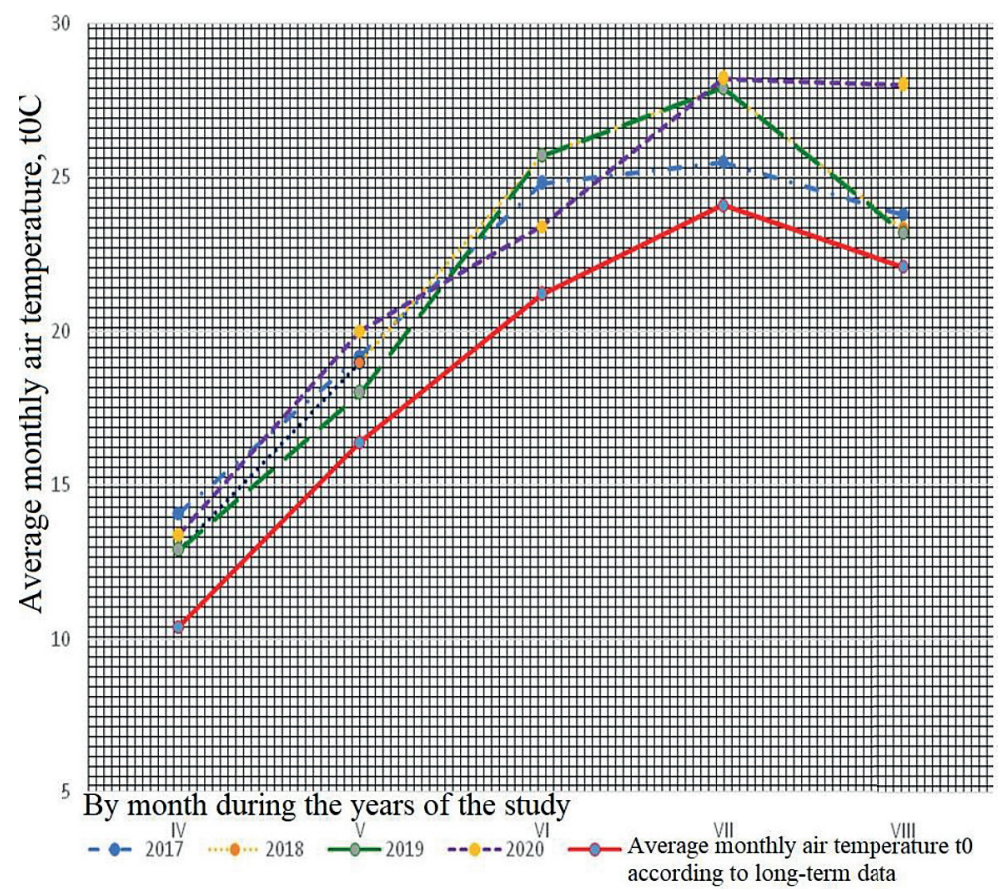

Figure 4. Climate changes in the years of the study during rapeseed cultivation by the parameters of the average annual air temperature during the growing season, $\mathrm{t}^{\circ} \mathrm{C}$ 
2017]. Therefore, when solving the problem of adapting the technology of rapeseed cultivation to the specific conditions of change and impart stability to the agroecosystem, the soil protection technology with a minimum technogenic impact on soil fertility and the productivity of the rapeseed agroecosystem was studied.

It should be noted that the application of the mini-till technology reduces the number of mechanical soil cultivation by half. This technology replaces the systems of mechanical pre-sowing and intermediate soil cultivation in the fight against weeds at the sowing fields with environmentally friendly doses of herbicides. At the same time, the use of environmentally correct methods of technology fits into the biochemical cycle of resources of the agroecosystem and ensures the creation of a sustainable competitive agrophytocenosis [Ageichik and Poloznyak, 2004; Belik, 2003].

In the Research and Production Center (RPC) named after A. I. Baraev, an international scientific conference was organized to discuss the "Diversification of crop production and no-till technology as the basis for saving agriculture and food security." Scientists and industrialists from Canada, the USA, Russia, Ukraine, and Kazakhstan spoke at the conference, presenting the issues of further agriculture development in the context of diversification of crop production and no-till technology as the basis for saving agriculture and providing food security of the corresponding countries [Kiryushenov, 2013].

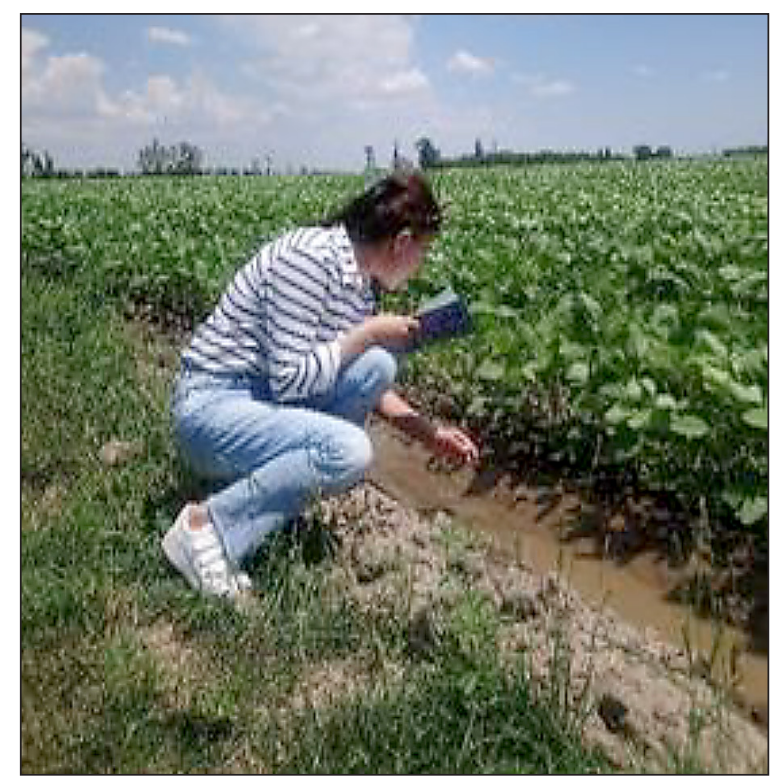

Figure 5. Determination of the density of rapeseed herbage in the field experiment
In the field experiment, the control variant represented the traditional moldboard cultivation with factor $\mathrm{A}_{1}$, plowing the soil with a PN-5-35 at the depth of $20-22 \mathrm{~cm}$. The studied variants of resource-saving technology $A_{2}$ and $A_{3}$ were evaluated in comparison with the environmental situation of this control variant, $\mathrm{A}_{1}$.

The analysis of the influence of soil-protective flat-cut tillage on the addition of the arable layer in terms of volumetric weight, aggregate composition, and structure of the soil indicates a decrease in the level of soil fertility in the rapeseed agroecosystem. The results of studying the soil density by volumetric weight in dynamics show that with the traditional system of soil cultivation, the maximum anthropogenic effect of moldboard plowing is manifested, which causes a loose addition of the arable soil layer. In the initial period of the rapeseed growing season, the density of the arable soil layer rapidly decreases from $1.22 \mathrm{~g} / \mathrm{cm}^{3}$ to $0.09 \mathrm{~g} / \mathrm{cm}^{3}$. On average, the volumetric weight is $1.06 \mathrm{~g} / \mathrm{cm}^{3}$. An increased physical evaporation of moisture with subsequent deterioration of the water regime of sowing rapeseed was observed (Table 2).

With resource-saving technology, where soilprotective protection flat-cutting tillage (at the depth of 16-18 and 12-14 cm) is performed, it provides an optimal soil density in the range of $1.18 \mathrm{~g} / \mathrm{cm}^{3}$ and $1.21 \mathrm{~g} / \mathrm{cm}^{3}$ on average.

The dynamics of the volumetric weight of the arable layer of soil show that during the growing season, the density of the soil increases

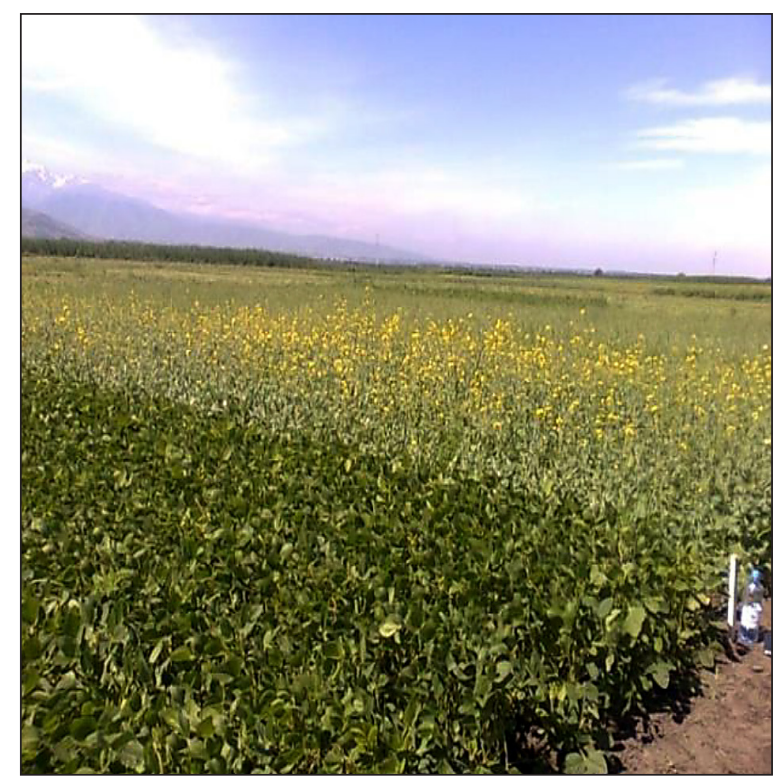

Figure 6. The onset of rapeseed phenophase, flowering 
Table 2. Influence of soil-protective resource-saving technology on agrophysical factors of soil fertility in the agroecosystem of rapeseed (average data over 3 years)

\begin{tabular}{|c|c|c|c|c|c|c|c|c|c|}
\hline \multirow{2}{*}{$\begin{array}{l}\text { Factor A } \\
\text { techno- } \\
\text { logy }\end{array}$} & \multirow{2}{*}{$\begin{array}{l}\text { Factor B } \\
\text { main soil } \\
\text { tillage }\end{array}$} & \multicolumn{3}{|c|}{$\begin{array}{l}\text { Volumetric weight } \\
\text { of the soil } \mathrm{g} / \mathrm{cm}^{3}\end{array}$} & \multicolumn{3}{|c|}{$\begin{array}{c}\text { The number of } \\
\text { macroaggregates, } \\
\% \text { in the soil layer, } \mathrm{cm}\end{array}$} & \multirow{2}{*}{$\begin{array}{l}\text { The number of } \\
\text { water-resistant } \\
\text { aggregates, \% }\end{array}$} & \multirow{2}{*}{$\begin{array}{c}\text { Soil } \\
\text { structure } \\
\text { coefficient }\end{array}$} \\
\hline & & $\begin{array}{l}\text { In the soil } \\
\text { layer, } \mathrm{cm}\end{array}$ & $\begin{array}{l}\text { before } \\
\text { sowing }\end{array}$ & $\begin{array}{c}\text { before } \\
\text { harvesting }\end{array}$ & $0-10$ & $10-20$ & $0-20$ & & \\
\hline \multirow{3}{*}{ 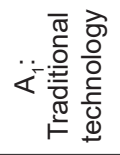 } & \multirow{3}{*}{$\begin{array}{l}B_{1} \text { : Plowing at the } \\
\text { depth of } \\
20-22 \mathrm{~cm}\end{array}$} & $0-10$ & 0.9 & 1.27 & \multirow{3}{*}{28.1} & \multirow{3}{*}{30.0} & \multirow{3}{*}{$29.0 \pm 1.11$} & \multirow{3}{*}{$22.3 \pm 0.66$} & \multirow{3}{*}{$0.57 \pm 0.011$} \\
\hline & & $10-20$ & 1.22 & 1.33 & & & & & \\
\hline & & $0-20$ & 1.06 & 1.30 & & & & & \\
\hline \multirow{6}{*}{ 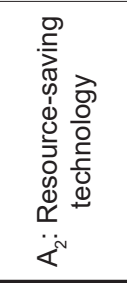 } & \multirow{3}{*}{$\begin{array}{l}\mathrm{B}_{2} \text { : Flat-cut tillage } \\
\text { at the depth of } \\
16-18 \mathrm{~cm} \\
\text { (+pulse, } 0.7 \mathrm{l} / \mathrm{ha})\end{array}$} & $0-10$ & 1.18 & 1.28 & \multirow{3}{*}{45.8} & \multirow{3}{*}{43.2} & \multirow{3}{*}{$44.5 \pm 2.12$} & \multirow{3}{*}{$40.0 \pm 1.75$} & \multirow{3}{*}{$0.91 \pm 0.012$} \\
\hline & & $10-20$ & 1.28 & 1.34 & & & & & \\
\hline & & $0-20$ & 1.23 & 1.31 & & & & & \\
\hline & \multirow{3}{*}{$\begin{array}{l}\mathrm{B}_{3}: \text { Flat-cut tillage } \\
\text { at the depth of } \\
12-14 \mathrm{~cm} \\
(+ \text { pulse, } 07 \text { I/ha) }\end{array}$} & $0-10$ & 1.19 & 1.29 & \multirow{3}{*}{47.2} & \multirow{3}{*}{46.8} & \multirow{3}{*}{$47.0 \pm 1.75$} & \multirow{3}{*}{$41.5 \pm 2.09$} & \multirow{3}{*}{$0.90 \pm 0.013$} \\
\hline & & $10-20$ & 1.23 & 1.31 & & & & & \\
\hline & & $0-20$ & 1.21 & 1.30 & & & & & \\
\hline
\end{tabular}

significantly. The density of the soil is $0-20 \mathrm{~cm}$ of the soil layer by the end of the rapeseed growing season. With traditional technology involving moldboard plowing, the soil is compacted as much as possible, the volumetric weight increases from $1.06 \mathrm{~g} / \mathrm{cm}^{3}$ to $1.30 \mathrm{~g} / \mathrm{cm}^{3}$, and the soil is compacted significantly by $0.24 \mathrm{~g} / \mathrm{cm}^{3}$. Sharp compaction of the arable layer of soil by $18.5 \%$, causes a deviation in the water regime of the soil and numerous ruptures of the plant root system associated with sharp compaction.

The obtained density values $\left(1.06 \mathrm{~g} / \mathrm{cm}^{3}\right)$ with the traditional technology were much lower than the equilibrium density $\left(1.21-1.22 \mathrm{~g} / \mathrm{cm}^{3}\right)$ of the arable layer of the meadow-chestnut soil, which indicates a loose composition of the soil. This phenomenon is associated with the use of traditional technology, based on the use of moldboard tillage carried out by a PN-3-35 plow. Plowing turns the tilled layer by 135 degrees or more, and the plowed soil layer is completely mixed and loosened. The obtained results change the arable layer of the soil and are confirmed by the results of other studies [Bazdyrev, 2008; Podsiadłowski, 2005; Abildaev and Suleymenova, 2017].

Environmental monitoring carried out in the rapeseed agroecosystem allowed the authors to determine the environmental situation of the ecosystem and substantiate the effectiveness of resource-saving and traditional technologies in a comparative assessment of their cultivation. In the case of the soil-protective mini-till variants, the soil is compacted moderately during the growing season of rapeseed, and there are no risks for the developing root system of plants. With resource-saving technology, carried out by flat-cut soil tillage, the volumetric weight during the growing season of rapeseed was in the optimal density zone, within 1.21 to $1.23 \mathrm{~g} / \mathrm{cm}^{3}$, where the optimal composition of the topsoil is formed, providing the conditions for the normal growth and development of rapeseed. The analysis of the following indicators of soil fertility factors indicates the optimal structure of the soil of the arable horizon, where the content of valuable macro-aggregates increases from 44.5 to $47.4 \%$, the amount of water-resistant aggregates increases from 29.0 to $40.0-41.5 \%$, and the structural coefficient increases, on average from 0.56 to 0.98 , which indicates the restoration of good soil structure.

Thus, with resource-saving rapeseed cultivation technology, soil protection technology ensures the sustainability of the environmental situation of the soil environment, improves the structure, and increases the water-resistance of the soil aggregate of the agroecosystem, where the structure of the topsoil is stabilized, with an optimal density, which contributes to the normal growth, development, and productivity of rapeseed.

During the years of the study with traditional technology, the yield of rapeseed was $17.4 \mathrm{c} / \mathrm{ha}$, and with resource-saving technology, it increased to 19.6 to $21.1 \mathrm{c} / \mathrm{ha}$. The difference in yield, depending on the depth of flat-cut tillage, is $1.5 \mathrm{c} / \mathrm{ha}$, and in comparison with the traditional technology, the yield increases from 2.2 to $3.7 \mathrm{c} / \mathrm{ha}$. Thus, over the years of the study, it was observed that high yields were obtained with resource-saving technology (Table 3).

While studying the soil protection methods of the rapeseed agroecosystem, it was seen that the traditional technology of cultivation of 
Table 3. Economic efficiency of resource-saving soil protection technology of the agroecosystem of rapeseed in the conditions of South-East Kazakhstan

\begin{tabular}{|c|c|c|c|c|c|c|c|}
\hline $\begin{array}{l}\text { FactorA: } \\
\text { Technology }\end{array}$ & $\begin{array}{l}\text { Factor B } \\
\text { Main soil } \\
\text { tillage }\end{array}$ & $\begin{array}{l}\text { Average } \\
\text { yield, } \\
\text { c/ha }\end{array}$ & $\begin{array}{l}\text { Cost of } 1 \mathrm{c} \\
\text { of seeds, } \\
\text { thousand } \\
\text { tenge }\end{array}$ & $\begin{array}{l}\text { Revenue } \\
\text { from sales, } \\
\text { thousand } \\
\text { tenge }\end{array}$ & $\begin{array}{l}\text { Cost of growing } \\
\text { rapeseed, } \\
\text { thousand tenge }\end{array}$ & $\begin{array}{l}\text { Net operating } \\
\text { profit, } \\
\text { thousand } \\
\text { tenge }\end{array}$ & $\begin{array}{c}\text { Rapeseed } \\
\text { profitability, } \\
\%\end{array}$ \\
\hline $\begin{array}{l}\mathrm{A}_{1}: \text { Traditional } \\
\text { technology }\end{array}$ & $\begin{array}{l}B_{1}: \text { Plowing at the } \\
\text { depth of } 20-22 \mathrm{~cm}\end{array}$ & 17.4 & 7.8 & 135.72 & 89.7 & 46.02 & 52.0 \\
\hline \multirow{2}{*}{$\begin{array}{l}\mathrm{A}_{2} \text { : Resource- } \\
\text { saving } \\
\text { technology }\end{array}$} & $\begin{array}{l}\mathrm{B}_{2}: \text { Soil-protective } \\
\text { flat-cut tillage at the } \\
\text { depth of } 16-18 \mathrm{~cm} \\
+ \text { pulse, } 0.7 \mathrm{I} / \mathrm{ha}\end{array}$ & 19.6 & 7.8 & 152.88 & 77.6 & 75.28 & 97.0 \\
\hline & $\begin{array}{l}\mathrm{B}_{3} \text { Soil-protecting } \\
\text { flat-cut tillage at the } \\
\text { depth of } 12-14 \mathrm{~cm} \\
+ \text { pulse, } 0.7 \mathrm{I} / \mathrm{ha}\end{array}$ & 21.1 & 7.8 & 164.58 & 79.2 & 85.38 & 108.0 \\
\hline
\end{tabular}

crops caused many negative consequences. The regularity of changes in the composition of the arable layer of the soil as a result of the application of the mini-till technology improves with an increase in the quality indicators of soil fertility resources. The agrophysical factors of soil fertility are restored, the environmental situation is optimized and the yield increases significantly by 12.6 and $21.3 \%$.

Increasing the productivity of the grown rapeseed crop leads to its economic efficiency. The economic efficiency of the resource-saving technology of rapeseed cultivation in comparison with the traditional one has shown an advantage, with a significant increase in yield, based on an increase in the sustainability of the agroecosystem associated with the restoration of soil fertility resources.

With the traditional technology for the cultivation of rapeseed with a yield of $17.4 \mathrm{c} / \mathrm{ha}$, direct costs amounted to 89.7 thousand tenges/ha. According to the sale of the harvest, the proceeds amounted to 135.72 thousand tenges/ha, and the net operating profit was 46.02 thousand tenges/ ha, which ensured the profitability of rapeseed cultivation by a total of $52.0 \%$. With the use of the elements of resource-saving technology, such as soil protection flat-cut tillage, the costs are reduced,

- firstly, due to a decrease in the volume of fuels and lubricants (FL) (amounting to 12.1 thousand tenge/ha) when replacing energy-intensive tillage such as plowing,

- secondly, the use of an environmentally safe minimum dose of herbicide to control weeds at the plots with rapeseed reduces the cost of cultivating rapeseed, from 89.7 to 77.6 and 79.2 thousand tenge/c.
A comparative assessment of economic indicators from the use of resource-saving technologies shows that the minimization of soil cultivation had contributed to an increase in income from 46.02 thousand tenges/ha to $75.28-85.38$ thousand tenge/ha with an increase in the profitability of rapeseed cultivation up to $97 \%$ and $108 \%$ in the conditions of South-East Kazakhstan.

Thus, in solving the targeted problem, the modern environmental situation and substantiated ways to solve the problem of the agroecosystem in the field of environmental safety with resource-saving technology of rapeseed cultivation were studied and identified. The stability and productivity of the agroecosystem of the oilseed crop such as rapeseed were revealed with mini-till, ensuring the restoration of soil fertility resources and stabilizing the condition of the agroecosystem with a minimum cost per unit of production.

\section{CONCLUSIONS}

1. On the basis of the results of the environmental monitoring of the sustainability and productivity of the agroecosystem of oilseeds under the conditions of South-East Kazakhstan, aggravation of the environmental problems of the agroecosystem associated with aridity and deterioration of soil fertility, which has a significant impact on the productivity of the agroecosystem of rapeseed was observed.

2. In order to optimize the environmental situation of the ecosystem and increase the productivity of the rapeseed crop, the studied soil protection methods of resource-saving technologies showed the feasibility of replacing energy-intensive moldboard tillage used with 
traditional technologies with the use of minitill combined with soil-protective resourcesaving technologies that ensure the rational use of soil resources and resource energy saving.

3. For the first time, the possibility of resource and energy saving in the agroecosystem of South-East Kazakhstan has been established. The restored parameters were determined, where the qualitative and quantitative indicators of the soil fertility of the agroecosystem are increased and the total energy consumption is reduced by $22.7-29.9 \%$ due to (fuel consumption) reduction in the cost of FL with mini-till according to resource-saving technology. In comparison with moldboard cultivation (plowing to a depth of 20-22 cm) with mini-till, the costs decrease from 10.5 thousand tenges/ha to 12.1 thousand tenges/ha.

4. It was established that soil protection methods of resource-saving rapeseed cultivation technology mitigate the risk of drought with high temperatures, optimize the conditions for the growth and development of crops, where productivity rises to $21.3 \%$, provide 29.3 thousand tenge/ha of additional income from each hectare, increasing the profitability of rapeseed cultivation up to $97 \%$ and $108 \%$ under the conditions of South-East Kazakhstan.

\section{REFERENCES}

1. Abildaev, E.S., Suleymenova, N.Sh. 2017. Influence of resource-saving technology methods on productivity of rape agroecosystems. Izdenistep, nətijeler [Studies and results], 3(75), 140-147.

2. Ageichik, V.V., Poloznyak, E.N. 2004. Zashchita rapsa ot vreditelei, boleznei i sornyakov v Respublike Belarus [Protection of rapeseed from pests, diseases and weeds in the Republic of Belarus]. Mat. mezhd. konf. "Khimicheskii metod zashchity rastenii" [Materials of the international conference "Chemical method of plant protection"], 3-4 (in Russian).

3. Ashabokov, B.A. 2012. Nekotorye problemy i metody adaptatsii agrarnogo sektora $\mathrm{k}$ izmeneniyu klimata [Some problems and methods of adaptation of the agricultural sector to climate change]. Regionalnye effekty globalnykh izmenenii klimata (prichiny, posledstviya, prognozy): Materialy mezhdunar. nauch. konf. [Regional effects of global climate change (causes, consequences, forecasts): Proceedings of the international scientific conference], Voronezh, Russia, June 26-27, 2012. Izd-vo Nauchnaya kniga, Voronezh, 360-365 (in Russian).
4. Ashikhmina, T.Y. 2008. Ekologicheskii monitoring [Environmental monitoring]. Akademicheskii proekt, Moscow, 416 p. (in Russian).

5. Bazdyrev, G.I. 2008. Istoriya razvitie zemledelia [History of agriculture development]. Zemledelie. Uchebnik [Agriculture. A manual]. KolosS, Moscow, 7-18.

6. Belik, N.L. 2003. Biologicheskie osnovy tekhnologii vozdelyvaniya rapsa yarovogo i redki maslichnoi $\mathrm{v}$ Tsentralnom Chernozeme [Biological bases of the technology of cultivation of spring rapeseed and oil radish in the Central Black Earth Region]. Avtoref. dis. d-ra s.-kh. nauk [Author's abstract of a Candidate of Agricultural Sciences dissertation]. Moscow Agricultural Academy named after K. A. Timiryazev, Moscow, 41 p. (in Russian).

7. Belkov, G.I., Ed. 2011. Innovatsiya i modernizatsiya selskokhozyaistvennogo proizvodstva v usloviyakh menyayushchegosya klimata: materialy mezhdunarodnoi nauchno-prakticheskoi konferentsii [Innovation and modernization of agricultural production in a changing climate: proceedings of the international research and practice conference]. GNU Orenburg. NII sel. khoz-va RASKhN, Orenburg, 362 p. (in Russian).

8. Bykova, A.V., Maltseva, N.E., Pavlova, D.S., Subbotina, M.N., Soklakova, O.S., Lukashova, O.P. 2014 Vliyanie izmeneniya klimata na selskoe khozyaistvo [Impact of climate change on agriculture]. Yestestvennyye i matematicheskiye nauki v sovremennom mire (Natural and math sciences in the modern world), 14, 114-121 (in Russian).

9. Daribaeva, E.B. 2019. Clustering as a mechanism of economic growth of the agro-industrial complex of Kazakhstan. Journal of Advanced Research in Law and Economics, Letter of Acceptance for Publication No. 433 of 07.11.2019.

10. Dmitrenko, V.P., Sotnikova, E.V., Chernyaev, A.V. 2014. Ekologicheskii monitoring tekhnosfery: Uchebnoe posobie [Environmental monitoring of the technosphere: a manual]. Lan, St. Petersburg, 368 p. (in Russian).

11. Dogeev, G.D., Khalilov, M.B. 2019. Resursosberegayushchie tekhnologii i mashiny dlya obrabotki pochvy [Resource-saving technologies and machines for soil tillage]. Problemy razvitiya APK regiona, 2(38), 58-65 (in Russian).

12. Dospekhov, B.A. 1985. Metodika polevogo opyta [Methods of field experiments]. Agropromizdat, Moscow, 351 p. (in Russian).

13. Egorov, V.P., Toncheva, N.N., Samsonov, A.N. 2018. Sposoby obrabotki pochvy pri pochvozashchitnykh tekhnologiyakh [Tillage methods for soil protection technologies]. Sovremennoe sostoyanie i perspektivy razvitiya nauki, tekhniki i obrazovaniya: sb. nauch. tr. po materialam Vseros. nauch.- prakt. konf 
[Current state and prospects for the development of science, technology and education: a collection of papers presented at the All-Russian research and practice conference], 47-50 (in Russian).

14. Eleshev, R.E., Balgabayev, A.M., Ramazanova, R.H., Salykova, A.S. 2014. Praktikum po agrokhimii [Workshop on agrochemistry]. Almanac, Almaty, 264 p. (in Kazakh).

15. Fedotov, V.I., Kurolap, S.A., Akimov, L.M., Degtyarev, S.D., Dmitrieva, V.A., Derevyagina, M.V. 2012. Regionalnye effekty globalnykh izmenenii klimata (prichiny, posledstviya, prognozy) [V t.ch. vliyanie klimaticheskikh izmenenii na produktivnost s.-kh. kultur]: Materialy mezhdunarodnoi nauchnoi konferentsii [Regional effects of global climate change (causes, consequences, forecasts) [Incl. the influence of climatic changes on the productivity of crops]: Materials of the international scientific conference], Voronezh, Russia, June 26-27, 2012. Izd-vo Nauchnaya kniga, Voronezh, 576 p. (in Russian).

16. Filipova, M., Zheleva, I., Sulejmenova, N., Abildaev, E. 2017. An analysis of growth factors of rapeseed at modern resource-saving technology. AIP Conference Procedings, 1895(1), 030001.

17. Ivanov, V.A. 2008. Metodologicheskie osnovy innovatsionnogo razvitiya agropromyshlennogo kompleksa [Methodological foundations of innovative development of the agro-industrial complex]. Ekonomicheskie i sotsialnye peremeny: fakty, tendentsii, prognoz, 2, 17-19 (in Russian).

18. Karpov, S.N., Kozhukhov, A.A., Gerasimov, E.V., Khaustov, P.A. 2019. Tekhnologii pochvozashchitnoi obrabotki: puti razvitiya [Soil conservation technologies: development paths]. Vestnik APK Stavropolya, 1(33), 8-13 (in Russian).

19. Khalilov, M.B., Khalilov, S.M., Zhuk, A.F. 2016. Pochvovlagosberegayushchie agropriemy pri vozdelyvanii zernovykh kultur v usloviyakh respubliki Dagestan [Soil and moisture-saving agricultural practices in the cultivation of grain crops in the conditions of the Republic of Dagestan]. Problemy razvitiya APK regiona, 1|(1-2(25)), 119-123 (in Russian).

20. Kiryushenov, V. 2013. No-till - filosofiya zemlepolzovaniya KhKhI veka [No-till as a philosophy of land use of the 21st century]. Sb. trudov. Mezh.nar. nauch.prak.konf "Diversifikatsiya rastenievodstva i No-till kak osnova sberegayushchego zemledelie i prodovolstvennaya bezopasnost" [A collection of papers presented at the international research and practice conference "Diversification of crop production and no-till technology as the basis for saving agriculture and food security"'], 15-20 (in Russian).

21. Kiryushin, B.D., Usmanov, P.P., Vasilev, I.P. 2009. Osnovy nauchnykh issledovanii $\mathrm{V}$ agronomii
[Fundamentals of scientific research in agronomy]. KolosS, Moscow, 398 p. (in Russian).

22. Kokorin, A.O., Garnak, A., Gritsevich, I.G., Safonov, G.V. 2008. Ekonomicheskoe razvitie i reshenie problemy izmeneniyaklimata [Economic development and solving the problem of climate change]. Datskoe energeticheskoe agentstvo, Moscow, 32 p. (in Russian).

23. Kuandykova, E., Suleimenova, N., Kyrmanbayeva, M., Raimbekova, D., Zharibekova, A. 2020. Efficiency ofsoy's bioecological feature in improving soil fertility and its productivity in conditions of south-east of Kazakhstan. Eurasian Journal of BioSciences, 14(1), 493-500.

24. Lukomets, V.M. 2007. Metodika provedeniya polevykh agrotekhnicheskikh opytov s maslichnymi kulturami [Methods for conducting field agrotechnical experiments with oilseeds]. VNIIMK, Krasnodar, 112 p. (in Russian).

25. Magomedov, N.R., Khalilov, M.B., Bedoeva, S.V. 2017. Resursosberegayushchie priemy obrabotki pochvy pod ozimuyu pshenitsu v ravninnoi zone Dagestana [Resource-saving methods of tillage for winter wheat in the plain zone of Dagestan]. Rossiiskaya selskokhozyaistvennaya nauka, 1, 33-35 (in Russian).

26. Minnebaeva, I.F. 2011. Vliyanie resursosberegayushchikh priemov osnovnoi obrabotki pochvy i pryamogo poseva (No-till) na gumusnoe sostoyanie chernozema vyshchelochennogo yuzhnoi lesostepi Respubliki Bashkortostan. Dis. k.s.-kh.n., spetsialnost 06.01.01 - obshchee zemledelie [Influence of resource-saving methods of basic tillage and direct (no-till) sowing on the humus state of the leached chernozem in the southern forest-steppe of the Republic of Bashkortostan. Candidate of Agricultural Sciences dissertation, program 06.01.01 - general farming ]. Bashkir State Agrarian University, Ufa, 45 p. (in Russian).

27. Mironova, A.V., Liskin, I.V., Kostomakhin, M.N., Nagorny, V.D. 2019. Pochvozashchitnye tekhnologii i energosberegayushchaya tekhnika dlya vozdelyvaniya selskokhozyaistvennykh kultur [Conservation technologies and energy-saving equipment for the cultivation of crops]. Selskokhozyaistvennaya tekhnika: obsluzhivanie i remont, 3, 9-15 (in Russian).

28. Murugov, V.P., Pinov, A.B. 1996. Strategiya razvitiya vozobnovlyaemoi energetiki vselskom khozyaistve Rossii [Development strategy for renewable energy in the Russian agricultural sector]. In: Netraditsionnaya energetika, resursy, tekhnika, ekonomika, ekologiya. Sb. trudov "Sovremennye problemy netraditsionnoi energetiki" [Non-traditional energy, resources, technology, economics, ecology. Modern problems of non-traditional energy: a collection of papers]. Publishing house of 
St. Petersburg State Technical University, St. Petersburg, 41-46 (in Russian).

29. Novikov, A.M., Novikov, D.A. 2010. Metodologiya nauchnykh issledovanii [Methods of scientific research]. Librokom, Moscow, 280 p. (in Russian).

30. Podsiadłowski, S. 2005. The integrated tillage system in wind erosion control. Acta Agrophysica, 5(1), 111-20.

31. RASKhN. GNU VNII kormov im. V.R. Vilyamsa [Russian Academy of Agricultural Sciences. State Scientific Institution All-Russian Research Institute of Feed named after V.R. Williams]. 2011. Programma i metodika provedeniya nauchnykh issledovanii po lugovodstvu (po Mezhdunarodnoi koordinatsionnoi programme NIR Rosselkhozakademii na 2011-2012 gg.) [Program and methodology for conducting scientific research on meadow farming (according to the International Coordination Program of Scientific Research of the Russian Agricultural Academy for 2011-2012)]. FGU RTsSK, Moscow, 192 p. (in Russian).

32. Ryabtseva, N.A. 2019. Effektivnost tekhnologii vozdelyvaniya polevykh kultur na chernozeme obyknovennom Rostovskoioblasti. Puti povysheniya effektivnosti oroshaemogo zemledeliya [The effectiveness of technologies for the cultivation of field crops on ordinary chernozem of the Rostov region. Ways to improve the efficiency of irrigated agriculture]. Nauchno-prakticheskii zhurnal FGBNU RosNIIPM, 4(76), 59-65 (in Russian).

33. Shalyapina, I.P., Guseva, A.S. 2007. Sostoyanie i ekonomicheskaya effektivnost funktsionirovaniya maslozhirovoi promyshlennosti APK Tambovskoi oblasti [State and economic efficiency of the functioning of the fat-and-oil industry of the agro-industrial complex of the Tambov region]. Ekonomika selskokhozyaistvennykh i pererabatyvayushchikh predpriyatii, 10, 25-26 (in Russian).
34. Shi, X., Li, Zh., Liu, Ch. 2019. The influence of humidity and the concentration of cadmium in the soil on the growth and development of rapeseed seeds. Journal of Agricultural Resources and Environment, $36,71-78$.

35. Sistema vedeniya selskogo khozyaistva Almatinskoi oblasti: Rekomendatsii [Agricultural system of Almaty region: Recommendations]. 2005. TOO NurlyAlem, Almaty, 292 p. (in Kazakh).

36. Suleimenova, N.Sh., Filipova, M., Abildayev, E.S. 2018. Ways of rational use of agroecosystem's natural resources under rational resouce-saving technology. Asian Journal of Microbiology, Biotechnology \& Environmental Sciences, 20(1), 184-193.

37. Suleimenova, N.Sh., Orynbasarova, G.O. 2019. Produktivnost agroekosistemy maslichnykh kultur V usloviyakh izmeneniya klimata [Productivity of the agroecosystem of oilseeds in the context of climate change]. Issledovanie Rezultaty, 04(084), 223-229 (in Russian).

38. Sycheva, V.G., Myuller, L., Eds. 2018. Novye metody i rezultaty issledovanii landshaftov v Evrope, Tsentralnoi Azii i Sibiri: monografiya [New methods and results of landscape studies in Europe, Central Asia and Siberia: a monograph], Vol. 2. All-Russian Research Institute of Agrochemistry named after D.N. Pryanishnikov, Moscow, 74-78 (in Russian).

39. Tyumentseva, E.Y., Ed. 2018. Ekologicheskie problemy regiona i puti ikh razresheniya: materialy XII Mezhdunar. nauch.-prakt. konf. [Environmental problems of the region and ways of their solution: materials of the 12th international research and practice conferencex, Omsk, Russia, May 15-16, 2018. Izd-vo OmGTU, Omsk (in Russian).

40. Zarch, M.A.A., Sivakumar, B., Malekinezhad, H., Sharma, A. 2017. Future aridity under conditions of global climate change. Journal of Hydrology, $554,451-469$. 